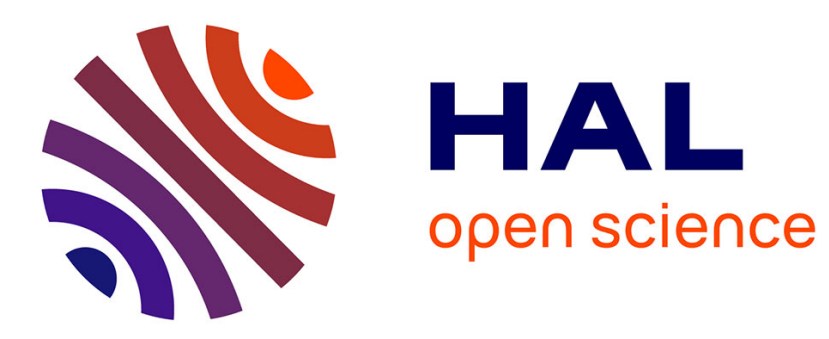

\title{
Rock coast erosion: an overlooked source of sediments to the ocean. Europe as an example
}

Vincent Regard, M. Prémaillon, Thomas Dewez, S. Carretier, C. Jeandel, Y. Godderis, S. Bonnet, J. Schott, Kevin Pedoja, J. Martinod, et al.

\section{- To cite this version:}

Vincent Regard, M. Prémaillon, Thomas Dewez, S. Carretier, C. Jeandel, et al.. Rock coast erosion: an overlooked source of sediments to the ocean. Europe as an example. Earth and Planetary Science Letters, 2022, 579, pp.117356. 10.1016/j.epsl.2021.117356 . hal-03504655

\section{HAL Id: hal-03504655 \\ https://hal.science/hal-03504655}

Submitted on 29 Dec 2021

HAL is a multi-disciplinary open access archive for the deposit and dissemination of scientific research documents, whether they are published or not. The documents may come from teaching and research institutions in France or abroad, or from public or private research centers.
L'archive ouverte pluridisciplinaire HAL, est destinée au dépôt et à la diffusion de documents scientifiques de niveau recherche, publiés ou non, émanant des établissements d'enseignement et de recherche français ou étrangers, des laboratoires publics ou privés. 


\title{
Rock coast erosion: an overlooked source of sediments to the ocean. Europe as an example
}

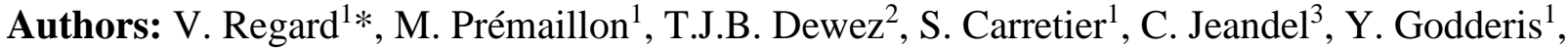

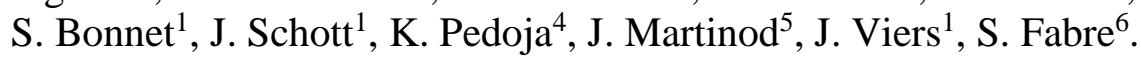

Short Title: Coastal erosion: a major sediment source

\section{One Sentence Summary:}

The erosion of the European rock coasts provides sediment fluxes to the ocean that are comparable to river fluxes.

\section{Highlights:}

- Sediment fluxes from eroding rock coasts are calculated at the European scale

- This flux of sediment is one third of the river sediment flux in Europe.

- This overlooked sediment source is significant by its signature in sedimentary records

- This sediment source is significant for balancing the oceanic geochemistry

\section{Affiliations}

${ }^{1}$ GET, Université de Toulouse, CNRS, UPS(OMP), IRD, CNES, 14 av. E. Belin, F-31400 Toulouse, France.

${ }^{2}$ BRGM, F-45060 Orléans, France.

${ }^{3}$ LEGOS, Université de Toulouse, CNRS, UPS(OMP), IRD, CNES, 14 av. E. Belin, 31400 Toulouse, France.

${ }^{4}$ M2C, Normandie Univ., Unicaen, Unirouen, CNRS, M2C 1400, Caen, France.

${ }^{5}$ Univ. Grenoble Alpes, Univ. Savoie Mont Blanc, CNRS, IRD, IFSTTAR, ISTerre, 38000 Grenoble, France

${ }^{6}$ IRAP, Université de Toulouse, CNRS, UPS(OMP), CNES, 14 av. E. Belin, 31400 Toulouse, France

*Correspondence to: vincent.regard@get.omp.eu. Ph:+33 561332645 


\section{Abstract}

Current assessments of the continent-to-ocean sediment budget assume that river discharge provides 11-21 Gt/a (72-89\%) of the global sediment flux to the ocean. The remaining 11$28 \%$ supposedly comes mainly from glacially-derived sediments and airborne dust. Until recently, the contribution from rock coasts was estimated to represent $0.4 \mathrm{Gt} / \mathrm{a}$, representing only 2-4\% of the total flux. For the first time, and using the most complete global compilation of sea cliff recession rates in Europe, this study evaluates the rock coast contribution to sediment flux. We show that this sediment flux has been largely underestimated, and reveal that cliff derived sediment supply is only three times less than the solid discharge of rivers $(111 \pm 65 \mathrm{vs.} 290 \mathrm{Mt} / \mathrm{a})$ for Europe. This new estimate of the rock coast erosion should be included in future studies on the evolution of the surficial Earth system.

\section{Graphical abstract}

Main erosive processes that supply sediment to the ocean

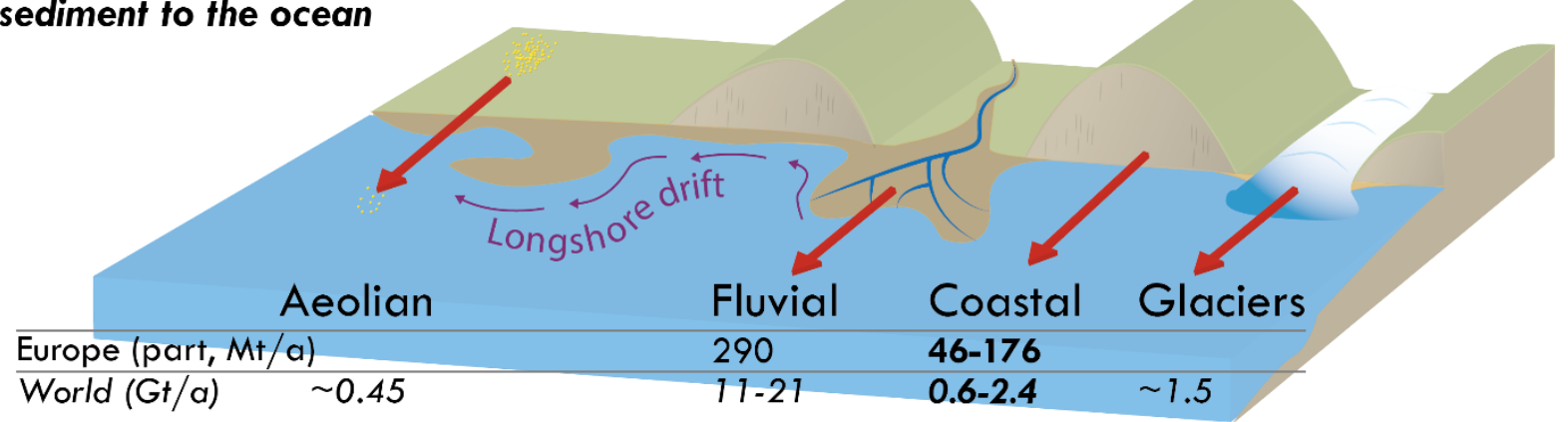

\section{Keywords}

Seacliff; Rock coast; Europe; Sediment budget; Coast; Erosion; Geochemical budget; Quaternary 


\section{Introduction}

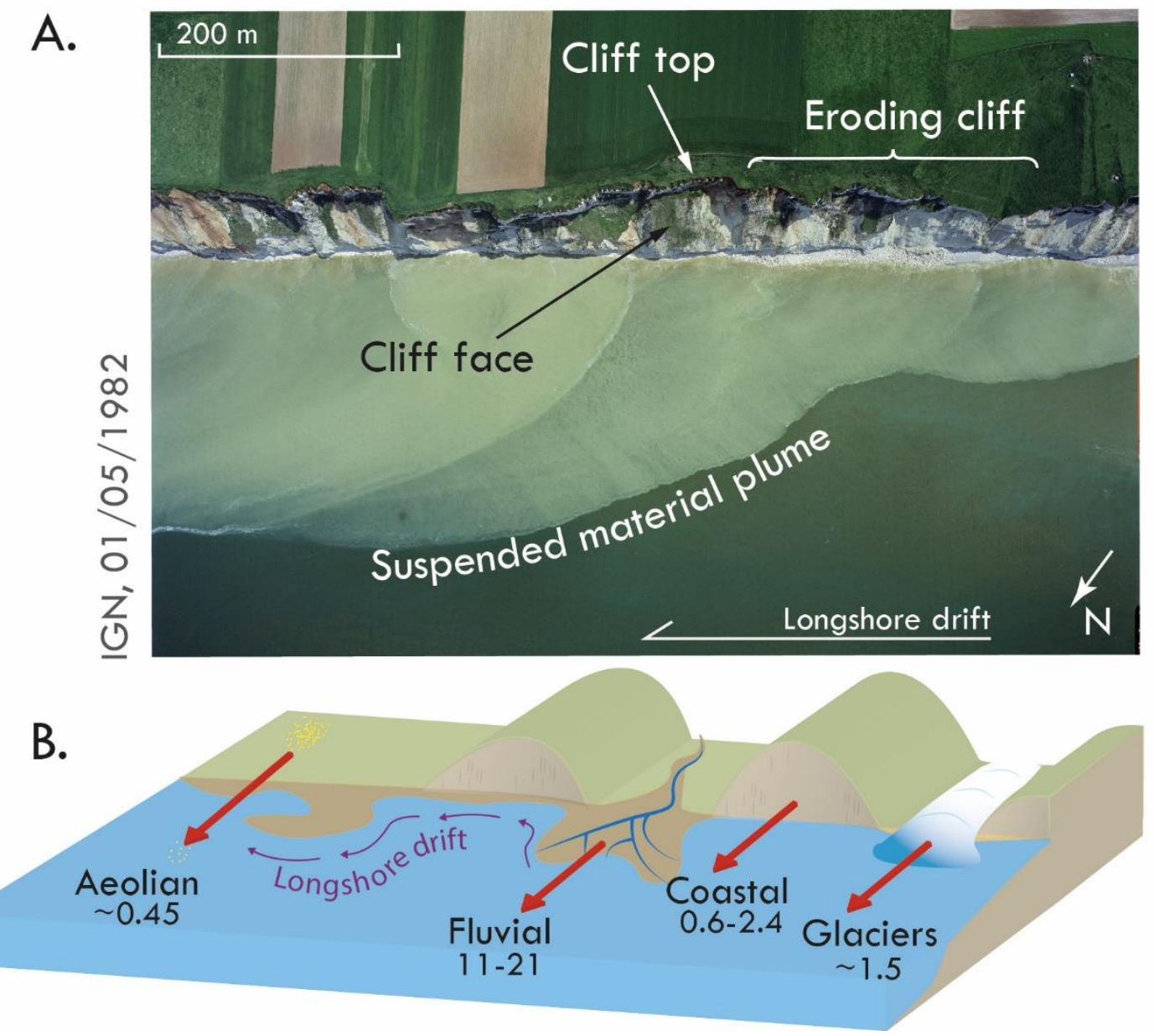

Fig. 1. Illustrations of the different sources of sediment to the ocean. (A) Aerial photograph displaying suspended sediment plumes of debris produced by cliff collapse ( $100 \mathrm{~m}$ high cliff close to Dieppe, Normandy, France, English Channel coast). (B) Sediment supply sources brought by fluvial, glacial (Raiswell et al., 2006) and aeolian transports (Hay, 1998; Jickells et al., 2005; Mahowald et al., 2005). The rock shore represents a major additional source (labelled "coastal"). Sedimentary coastal traps such as beaches or mudflats only temporarily store sediments, their erosion (either physical or chemical) at a later time only corresponds to the remobilization of sediments that are already in the coastal system (e.g. Sabatier et al., 2006). The numbers indicate the sediment global annual fluxes in Gt/a, evaluated from the literature and our own calculation for the coasts at the global scale (see data compilation Table S1; Milliman and Ren, 1995; Raiswell et al., 2006; Syvitski et al., 2003; Milliman and Farnsworth, 2011; Dedkov and Gusarov, 2006; Syvitski and Kettner, 2011; Ludwig and Probst, 1998; Milliman, 2001; Syvitski et al., 2005; Wilkinson and McElroy, 2007; Peucker-Ehrenbrink, 2009; Li et al., 2020; Hay, 1998; Mahowald et al., 2005; Jickells et al., 2005). 
Detrital sediment fluxes from continental and rock coast erosion are recorded in onshore and offshore basins (Belknap and Kraft, 1985; Nyberg et al., 2018). These fluxes exert a major control on the chemistry of the ocean and consequently the Earth system as a whole (Jeandel and Oelkers, 2015), including climate (Galy et al., 2007), and may also impact tectonics (Lamb and Davis, 2003). Up to now, it is widely accepted that rivers provide and have provided over geological timescales most of these sediment loads to oceans (Syvitski et al., 2003). However, sediment input to the ocean not only comes from rivers, but also from glaciers, continental aeolian transport and the erosion of rock coasts (Figure 1). Yet, among those various contributors, rock coast erosion has been overlooked. Here, we quantify the rock coast input to the ocean sediment budget at the European scale, where the most comprehensive dataset is available, and compare it to the river input.

Coastal systems are complex transfer zones between the continent and the ocean. The material eroded from the continent enters the ocean as solutes or sediment. According to current estimations (Supplementary Table S1), solid river discharge accounts for 72-89\% (11-21 Gt/a; Milliman and Ren, 1995; Syvitski et al., 2003; Milliman and Farnsworth, 2011; Dedkov and Gusarov, 2006; Syvitski and Kettner, 2011; Ludwig and Probst, 1998; Milliman, 2001; Syvitski et al., 2005; Wilkinson and McElroy, 2007; Peucker-Ehrenbrink, 2009; Li et al., 2020) of the total sediment flux to the oceans (Figure 1), followed by glacially-derived sediment $(6-11 \%, \sim 1.5 \mathrm{Gt} / \mathrm{a}$; Raiswell et al., 2006) and aeolian dust (2-3\%, 0.45 Gt/a; Hay, 1998; Jickells et al., 2005; Mahowald et al., 2005). Sediment input from the erosion of rock coasts has been crudely approximated as $2 \%$ of the global flux ( 0.4 Gt/a; Mackenzie and Garrels, 1971; Syvitski et al., 2003), a value poorly supported in the literature (beaches are not considered because their constitutive sediment is stored after having been already detached from the continent; Figure 1). This value leads to a ratio between coastal and river inputs $r$ of 0.02 to 0.04 . Yet, first-order evidence indicates that this flux is certainly underestimated, since the $5200 \mathrm{~km}$ coastline along the Laptev Sea already provides $\sim 0.06 \mathrm{Gt} / \mathrm{a}$ (Rachold et al., 2000). This is $\sim 15 \%$ of the global estimate, whereas the coastal length of the Laptev Sea accounts for only $0.3 \%$ of the global coast length.

\section{Material and methods}

\subsection{Methodology: overview}

The coastal erosion flux $F$ is expressed as $F=H_{\text {cliff }} \times V_{\text {retreat }} \times L_{\text {cliff }} \times \rho . H_{\text {cliff, }}$, the cliff height, $H_{\text {cliff, }}$ is evaluated from a DEM (Digital Elevation Model), $V_{\text {retreat }}$ is the average retreat rate depending on the rock resistance (e.g. hard, medium or soft resistance; Prémaillon et al., 2018), $L_{c l i f f}$ stands for the cliff length, and $\rho$ is the cliff rock density. Two complementary metrics allow defining the sedimentary flux from rock shores along the European coastline (mapped by the EMODnet European partnership, www.emodnet.eu; see paragraph 2.2), one of them being developed in this work. The first metric sums up the fluxes coming from the sites monitored for cliff retreat and compiled in the GlobR2C2 bibliographic database (Prémaillon et al., 2018). This flux reaches 20 $\mathrm{Mt} / \mathrm{a}$ for Europe. It is estimated from only $0.5 \%$ of the total European coastline length, and only $1.0 \%$ of its rock part. The second metric developed here (details in paragraph 2.2) is calculated from a cliff retreat parametric model. This model accounts for cliff height, rock density and rock hardness (Prémaillon et al., 2018; Young and Carilli, 2019). The results are spatialized based on 
the European rock coast classification defined by the EMODnet vector database (Figure 2). We adopted the EMODnet's working resolution of $100 \mathrm{~m}$. This turns out to be the typical spatial scale for the measured cliff erosion rates reported in GlobR2C2 (Prémaillon et al., 2018) (for details, refer to paragraph 2.3). Coastal erosion delivers solid and dissolved material to the ocean in varying proportions. Here we assume that a minimum of $90 \%$ of the coastal eroded volume goes to the ocean as sediment (see discussion on this point at the end of paragraph 2.2).
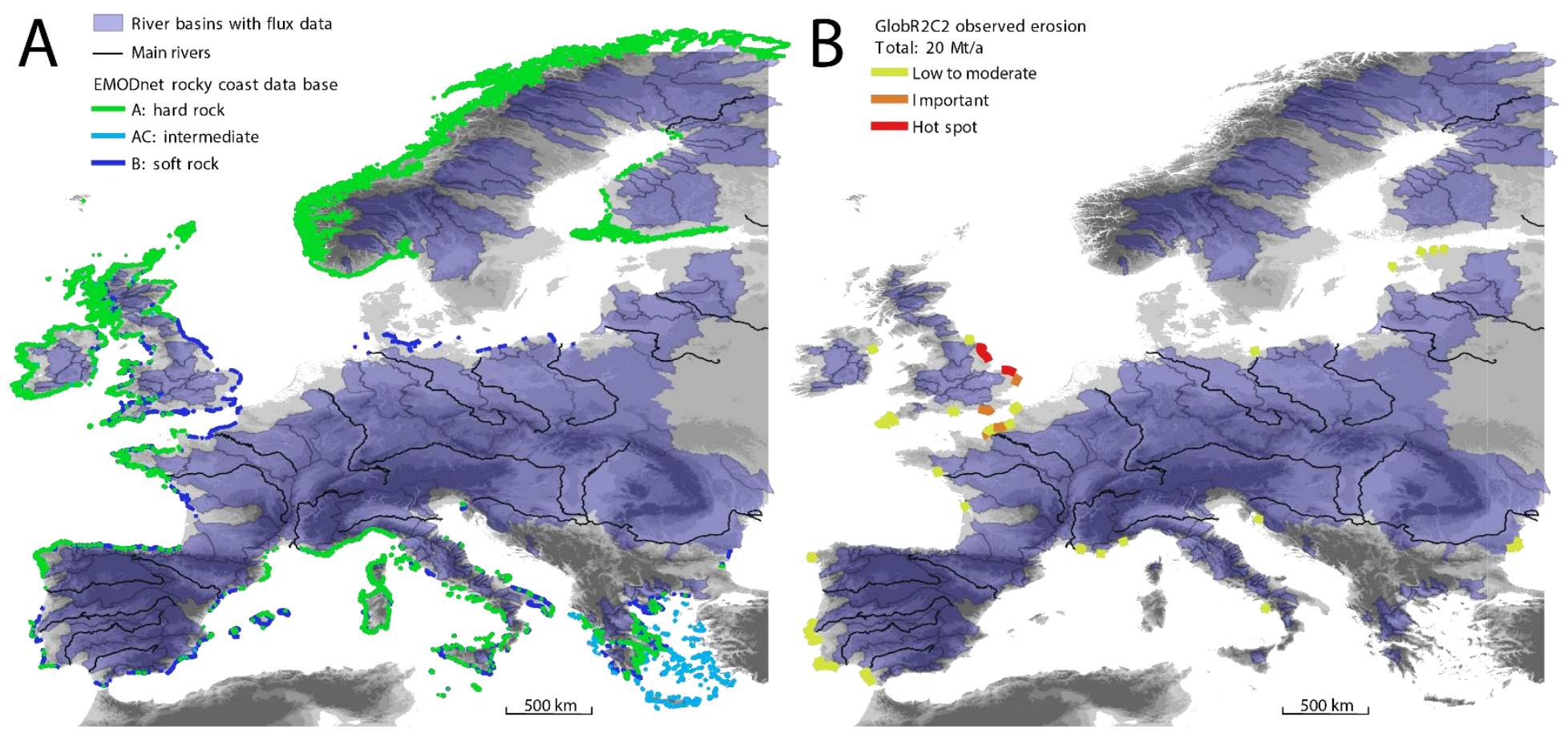

Fig. 2. Summary of the fluvial/coastal data available for Europe. The river flux database from Milliman and Farnsworth (2011), corresponding to the gray-blue-shaded areas, is then summarized for each basin (European Environment Agency). The background color from light gray to dark gray indicates the elevation (EU-DEM). Panel A figures the coastal rock hardness inferred from the EMODnet database: it is derived from a geology dataset, mainly based on lithology (see https://emodnet.ec.europa.eu/en/geology). Panel B shows the monitored cliff sites with recession velocity measurements, as compiled into the GlobR2C2 dataset. All together, these sites would provide up to $20 \mathrm{Mt} / \mathrm{a}$ (the "grand minimum") of sediments to the ocean.

In order to scale the rock coast sediment fluxes to other better-known contributions, we compare them to the suspended and dissolved fluxes of rivers. To this end, the European continent was first broken down into 29 hydrologically coherent basin districts (following the European Environment Agency segmentation, cf. paragraph 2.4). The present-day river fluxes from Milliman and Farnsworth (2011)'s database were aggregated for each basin district. Correcting these fluxes from the damming impact would increase the river solid discharge by ca $30 \%$, without affecting the flux spatial pattern across Europe (Supplementary Materials). Similarly, the coastlines were segmented at the limits of the basin districts, and the rock coast fluxes were aggregated for these entities 
(details in paragraph 2.4). The basins are broad enough to capture the signature of large catchments in which the upstream areas are well represented; conversely, in the downstream section where small coastal catchments occur, the sediment flux is not optimally captured. Five basin districts were excluded from the analysis due to the lack of cliff EMODnet rock hardness attributes (Danube, Angerman, Nemunas, Figure 3) or fluvial sedimentary discharge data (Tirso, Skjern, Figure 3). As a result, the analysis applies to 24 basin districts for which both coastal data and fluvial fluxes are simultaneously constrained (Figure 3). This captures $3.56 \times 10^{6} \mathrm{~km}^{2}$ of the European continent, bounded by $127 \times 10^{3} \mathrm{~km}$ of coast. The corresponding rock coast is $65 \times 10^{3} \mathrm{~km}$-long ( $52 \%$ of the total considered coastal length). This rock coast proportion is close to the global estimate (Luijendijk et al., 2018; Young and Carilli, 2019).

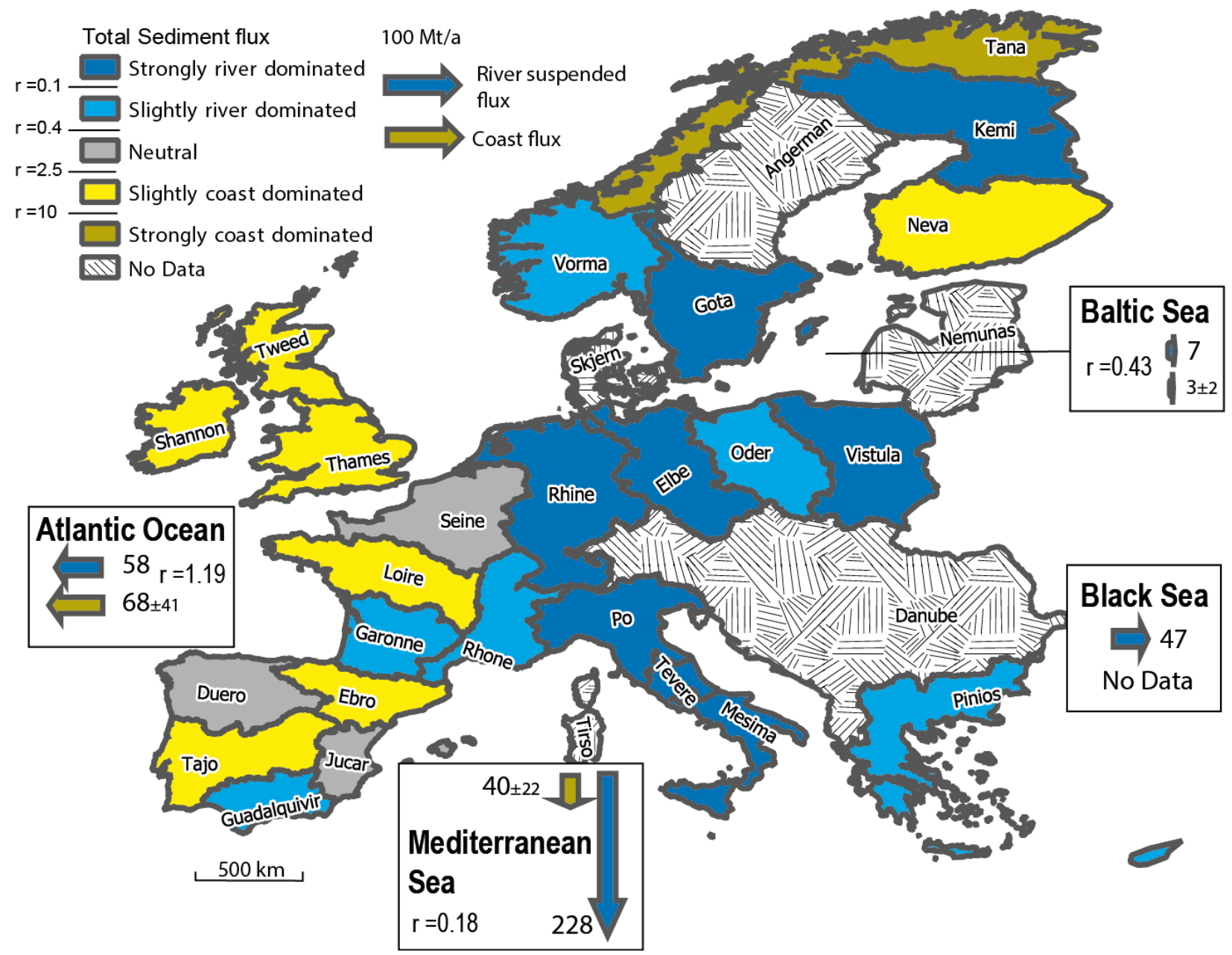

Fig. 3. Proportion of sedimentary contribution to the ocean (rock coast/river). A "strongly dominated" class indicates a ratio ( $r$ ) between both components larger than one order of magnitude $(r<0.1$ or $r>10)$. A "slightly dominated" class indicates a ratio $(r)$ between the coast and river contribution between 0.1 and 0.4 (river dominated), and between 2.5 and 10 (coast dominated). "Neutral" refers to the basin districts for which the ratio between the two components does not exceed $2.5(0.4<r<2.5)$. The total inputs into the different seas are shown by brown 
arrows for those of coastal origin and blue arrows for river solid discharge. A similar figure showing the pre-dam estimates is presented as Supplementary Material (Figure S1).

\subsection{Mass flux calculation from coasts}

We calculated two metrics: the first one assesses a minimum flux strictly based on observations; the second one extrapolates the likely sediment flux to the entire rock coastline of Europe.

The first metric (observation-based minimum) of rock coast sediment supply is the sum of sediment fluxes from the sites where the cliff erosion rates have been determined over a 1 to 100 years period and compiled in the GlobR2C2 database (Prémaillon et al., 2018). This equates to a $628 \mathrm{~km}$-long stretch of coastline, representing $0.5 \%$ of the $127.10^{3} \mathrm{~km}$-long coastline study area. The equivalent flux is computed in the same manner as for the general case (second metric).

The second metric represents the annual sedimentary flux $F$ of the rock coast computed along the coastline (i) as the product of the cliff height $H_{\text {cliff }}$ (ii), the cliff retreat rate $V_{\text {retreat }}$ (iii), the cliff length $L_{\text {cliff }}$ (iv), and the rock density $\rho(\mathrm{v}): F=H_{\text {cliff }} \times V_{\text {retreat }} \times L_{\text {cliff }} \times \rho$. (i) For the coastline, we use the Global Self-consistent Hierarchical High-resolution Geography dataset (GSHHG version 2.3.6 August 17, 2016). The GSHHG coastline derives from the SRTM 3 Arc-second Digital Elevation Model (DEM). (ii) As proposed by Prémaillon et al. (2018) and Young and Carilli (2019), the cliff height is evaluated as the third quartile DEM elevation value within a buffer of $\sim 100 \mathrm{~m}$ around the coastline. The DEM used is the EU-DEM, a raster dataset with elevations captured at 1 arc-per-second or approximately every 30 meters. It is a hybrid product based on SRTM and ASTER GDEM data that are fused by a weighted averaging approach (https://ec.europa.eu/eurostat/web/gisco/geodata/reference-data/elevation). The EU-DEM elevation value of 0 corresponds to sea level (vertical reference EVRS 2000). (iii) To assess cliff retreat at the continental scale, we combine a rock resistance index coming from the EMODnet coastal rock type classification. The EMODnet rock coast is classified into three classes, A, AC, and $\mathrm{B}$, which correspond respectively to hard rock, composite and soft rock coasts. Second, we use the results of Prémaillon et al. (2018), who classified the rocks into three types, based on an original, geotechnical parameter-based classification proposed by Hoek and Brown (1997). Using a worldwide compilation of 1 to 100 years observations, Prémaillon et al. (2018) showed that cliffs made of hard, intermediate, and soft rock retreat at different median rates of $0.029,0.10$, and 0.23 $\mathrm{m} / \mathrm{a}$, respectively. These are median values of the scattered data; using these lowers the weight of unusual quickly receding sea cliffs. A reasonable range of values corresponds to the $17 \%$ to $83 \%$ quantiles (the robust bounds of a $66 \%$ confidence interval), leading to associated uncertainty ranges of $0.019,0.04$, and $0.13 \mathrm{~m} / \mathrm{a}$, respectively. These retreat rates were then applied to the EMODnet A, AC, and B coasts, respectively. The influence of a hypothetical misclassification was tested by assigning the slowest erosion rate $(0.019 \mathrm{~m} / \mathrm{a})$ to every rock coast type. The result of this test still falls within the low range of our general estimate. At the monitored sites reported in the GlobR2C2 database, we used the cliff retreat rates instead of the rates extrapolated from the EMODnet classification. The spatial sampling of GlobR2C2 is variable; for example, the Scandinavian coasts are poorly documented (more information on this is available in Prémaillon et al., 2018). We assume that the related uncertainty falls within the large uncertainty of the final estimate (see the end of this paragraph). (iv) The cliff length is measured from the obtained EMODnet shapefile projected onto the closest GSHHG segments, because the two traces slightly 
differ and the GSHHG coastline corresponds to an elevation of 0 in the DEM. With regards to the coastal length, given the fractal nature of the coastline (Mandelbrot, 1967), decreasing the resolution to $10 \mathrm{~m}$ would double the coastline length and thus would double the cliff erosion flux (see $\S 2.3$ in which it is justified that $100 \mathrm{~m}$ is the most representative resolution). (v) We used densities of 2500,2400 and $2200 \mathrm{~kg} / \mathrm{m}^{3}$, respectively for the A, AC, and B rock shores. We evaluated the precision of the predicted sediment supply estimate using uncertainties of $10 \mathrm{~m}$ for the cliff height (Prémaillon et al., 2018), $200 \mathrm{~kg} / \mathrm{m}^{3}$ for the rock density and the $17 \%$ and $83 \%$ quantiles (see above) for the cliff rate measurements (Prémaillon et al., 2018) (details in Table 1). This led to a $\sim 66-176 \mathrm{Mt} / \mathrm{a}$ range $(111 \pm 65 \mathrm{Mt} / \mathrm{a})$. The lower bound is close to the value obtained if all of the coast types were set to the slowest recessing type (type A, $52 \mathrm{Mt} / \mathrm{a}$, Table 2).

Table 1. Detailed calculation of the sea cliff-sourced sediment flux. E is the cliff retreat (erosion) rate, $H$ is the cliff height (no value is given as it varies along the coast), $V$ is the annual volume sourced from the cliffs, $\rho$ is the material density considered, and $Q$ is the equivalent mass flux. The total flux is also given considering $90 \%$ of the total material eroded from the sea cliffs is the sedimentary (solid) input from the cliffs (rock coasts) to the ocean.

\begin{tabular}{lllllllllll}
\hline Coast type & Length & $\mathrm{E}$ & $+/-$ & $\begin{array}{l}\text { Uncertainty } \\
\mathrm{on} \mathrm{H}\end{array}$ & $\mathrm{V}$ & $+/-$ & $\rho$ & $+/-$ & $\mathrm{Q}$ & $+/-$ \\
& $(\mathrm{km})$ & $(\mathrm{m} / \mathrm{a})$ & & $(\mathrm{m})$ & $\left(\mathrm{x} 10^{6} \mathrm{~m}^{3} / \mathrm{a}\right)$ & $\left(\mathrm{kg} / \mathrm{m}^{3}\right)$ & & $(\mathrm{Mt} / \mathrm{a})$ \\
\hline A (hard rock) & 52846 & 0.029 & 0.019 & $10 \%$ & 15.7 & 10.4 & 2500 & 0.2 & 39 & 26 \\
B (soft rock) & 8326 & 0.23 & 0.13 & $10 \%$ & 31.6 & 18.1 & 2200 & 0.2 & 69 & 40 \\
AC (intermediate) & 4455 & 0.10 & 0.04 & $10 \%$ & 6.0 & 2.4 & 2400 & 0.2 & 14 & 6 \\
\hline Total & 65627 & & & & 53.3 & 31.0 & & & 123 & 73 \\
$(90 \%$ suspended) & & & & & & & & & 111 & 65 \\
\hline
\end{tabular}

Table 2. Minimum rock coast (cliff) sediment delivery. This table is similar to Table 1, but assigns the minimum value of the retreat rate for each cliff segment. Consequently, it provides a minimum estimate for cliff (rock coasts) sediment delivery.

\begin{tabular}{lllll}
\hline Coast type & $\begin{array}{l}\text { Length } \\
(\mathrm{km})\end{array}$ & $\begin{array}{l}\mathrm{E} \\
(\mathrm{m} / \mathrm{a})\end{array}$ & $\begin{array}{l}\mathrm{V} \\
\left(10^{6} \mathrm{~m}^{3} / \mathrm{a}\right)\end{array}$ & $\begin{array}{l}\mathrm{Q} \\
(\mathrm{Mt} / \mathrm{a})\end{array}$ \\
\hline A (hard rock) & 52846 & 0.029 & 15.7 & 39 \\
B (soft rock) & 8326 & 0.029 & 6.7 & 15 \\
AC (intermediate) & 4455 & 0.029 & 1.7 & 4 \\
\hline Total & 65627 & & 24.2 & 58 \\
$(90 \%$ suspended) & & & 21.8 & 52 \\
\hline
\end{tabular}


Coastal erosion processes are very poorly known; in particular, the fraction released by dissolution is generally neglected, even if a component of corrosion due to meteoric waters or living organisms (for example, via the variation in $\mathrm{pH}$ induced by the photosynthesis cycle; Higgins, 1980) cannot be ruled out (mostly discussed in the literature for carbonate rocks; Naylor et al., 2012). Recent laboratory experiments have shown that the fraction of Si released by dissolution ranges from 0.1 to $3 \%$ (Fabre et al., 2019). Here, we propose suspended material fluxes, making the conservative (i.e., leading to a minimum estimate of the sediment flux from eroding rock coasts) hypothesis of $10 \%$ rock dissolution at the coast (and 90\% eroded as solids). Consequently, the discussed metric corresponds to $90 \%$ of the volume lost by rock coasts estimated in the previous section. The second metric estimates the sediment discharge from the eroding rock coasts as $111 \pm 65 \mathrm{Mt} / \mathrm{a}$ (Table 1).

\subsection{Characteristic coastline dimension}

The fractal nature of the coast has been analyzed following Mandelbrot (1967), using the GSHHG coastline. The coastline data is delivered through five distinct resolutions (Wessel and Smith, 1996): (f) full resolution, containing the maximum resolution of the GSHHG data (about $120 \mathrm{~m}$, cf. Figure 4); (h) high resolution $(\sim 300 \mathrm{~m})$, obtained after a Douglas-Peucker line reduction to reduce the data size by $\sim 80 \%$ relative to full resolution; (i) intermediate resolution $(\sim 1000 \mathrm{~m})$, (1), low resolution $(\sim 5 \mathrm{~km})$, and (c) crude resolution $(\sim 20 \mathrm{~km})$, obtained after a Douglas-Peucker line reduction to reduce the data size by $\sim 80 \%$ relative to the high, intermediate and low resolution datasets, respectively (cf. Figure 4).

Based on the coastline datasets with different resolutions, the total coastline length was calculated as well as the median distance between two data points. This was processed for the entire dataset (worldwide) and for Europe (Figure 4). Similarly, the input data, GlobR2C2 and EMODnet are displayed at a resolution (median distance between two successive data points) of about $100 \mathrm{~m}$. Consequently, we used the full resolution coastline which is approximately at $100 \mathrm{~m}$, leading to a world's coastline of $1.83 \times 10^{6} \mathrm{~km}$-long; the coastal length in all of Europe is $\sim 0.231 \times 10^{6} \mathrm{~km}$ long whereas the coastal length in the study area is $0.127 \times 10^{6} \mathrm{~km}$.

The LGM and modern coastline length are similarly calculated using the paleo-elevation model ICE-6G_C taking into account glacio-isostatic motion and global sea level evolution (Peltier et al., 2015). We used raster maps from this model with a $\sim 60 \mathrm{~km}$ resolution (http://www.atmosp.physics.utoronto.ca/ peltier/data.php, Figure 4). An additional removal of glacial extent can be processed for the LGM coastline length following Ehlers et al. (2011). We also computed $\sim 2 \mathrm{~km}$ resolution LGM and modern coastlines (Figure 4) from CleanTOPO2 world MNT to which has been added the difference in elevation between $20 \mathrm{ka}$ BP and present (ICE6G_C model; Peltier et al., 2015). These evaluations suggest that the LGM coastline length was more than $20 \%$ shorter than the current one (27\% if considering ice-free coasts; Figure 4 ). 


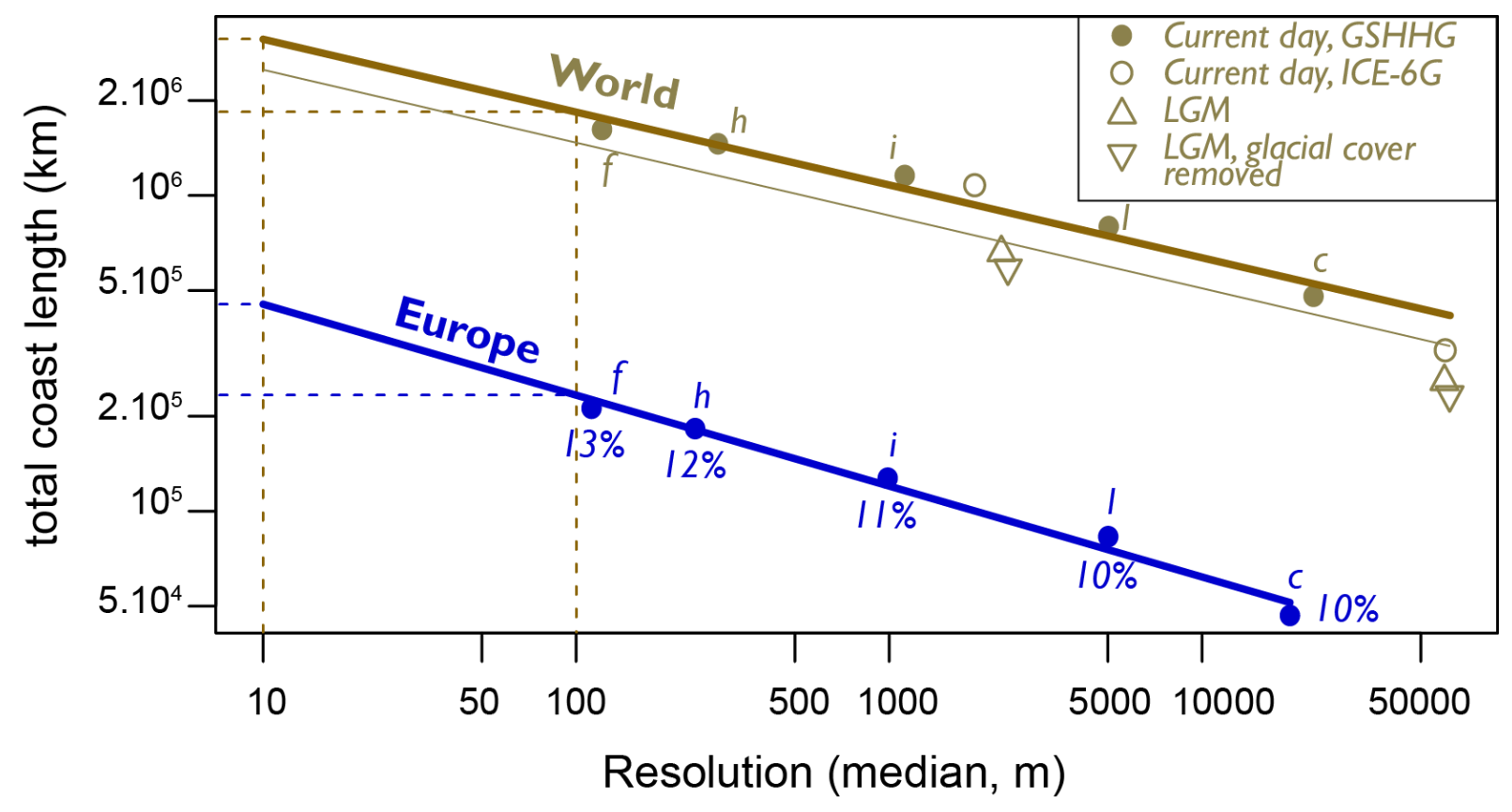

Fig. 4. Coast length as a function of its resolution (median distance between two consecutive points) for the world and for Europe (larger than the study area), from GSHHG (Wessel and Smith, 1996) dataset (filled circles). Letters stand for the GSHHG resolution: f, full; $h$, high; I, intermediate; $l$, low; $c$, crude (see text). Percentage numbers stand for the ratio of the length of the European to the world coastlines. The equations are length $=\exp (-0.231 * \ln ($ Resolution $)+$ $22.391)$ for the world coastline and length $=\exp (-0.288 * \ln ($ Resolution $)+20.59)$ for the European coastline. It predicts a world/Europe coast length of $1.83 .10^{6} / 0.231 \times 10^{6} \mathrm{~km}$ at a resolution of 100 $m$ and $3.11 .10^{6} / 0.449 \times 10^{6} \mathrm{~km}$ at a resolution of $10 \mathrm{~m}$. The coastline is approximately 1.7 to 1.9 times longer at a resolution of $10 \mathrm{~m}$ than at a resolution of $100 \mathrm{~m}$. Open symbols correspond to global coastline length evaluated for LGM. Triangles correspond to LGM coastline length calculated similarly to open symbols (current state) with model ICE-6G_C (Peltier et al., 2015). In addition, downward triangles correspond to LGM ice-free coastline length (upward triangles) (Ehlers et al., 2011). ICE-6G_C allows evaluations at $\sim 60 \mathrm{~km}$ resolution, calculated from maps provided by Peltier (http://www.atmosp.physics.utoronto.ca/ peltier/data.php). Evaluation at $\sim 2 \mathrm{~km}$ is calculated from CleanTOPO2 world MNT to which has been added the difference in elevation between $20 \mathrm{ka}$ BP and present (ICE-6G_C model; Peltier et al., 2015). These evaluations suggest that the LGM coastline length was more than $20 \%$ shorter than the current one (thin line; $27 \%$ if considering ice-free coasts).

\subsection{Basin district definition and sedimentary inputs from rivers}

In order to compare the sediment flux from rock coasts and rivers, we divided the study area into "basin districts", according to (European Environment Agency) (Figures 3 and 5). These administrative basin units merge major river catchments, minor river catchments and areas flowing directly to the sea. To establish the correspondence between river and coastal sediment fluxes, the 
coastline was segmented at the coastal boundaries of these basin districts and the basin district was labelled accordingly. This important operation connects land areas to their maritime façades. Taking the Rhone River as an example (Figure 5), the Rhone catchment extends far inland whereas its outlet is only a specific point. The European Environment Agency aggregated neighboring catchments to form the Rhone basin district as a unique and homogeneous hydro-geographic entity. This basin district has roughly similar river and coastline lengths (Figure 5). If we had limited ourselves to the boundaries of the large catchments, we would not have been able to take the contribution of the small adjacent sub-basins into account, and therefore the focus on a segment of the coastline would have been subjective. In other words, the discretization of the basin district makes it possible to link a continental hinterland with its maritime façade without any obvious imbalances.

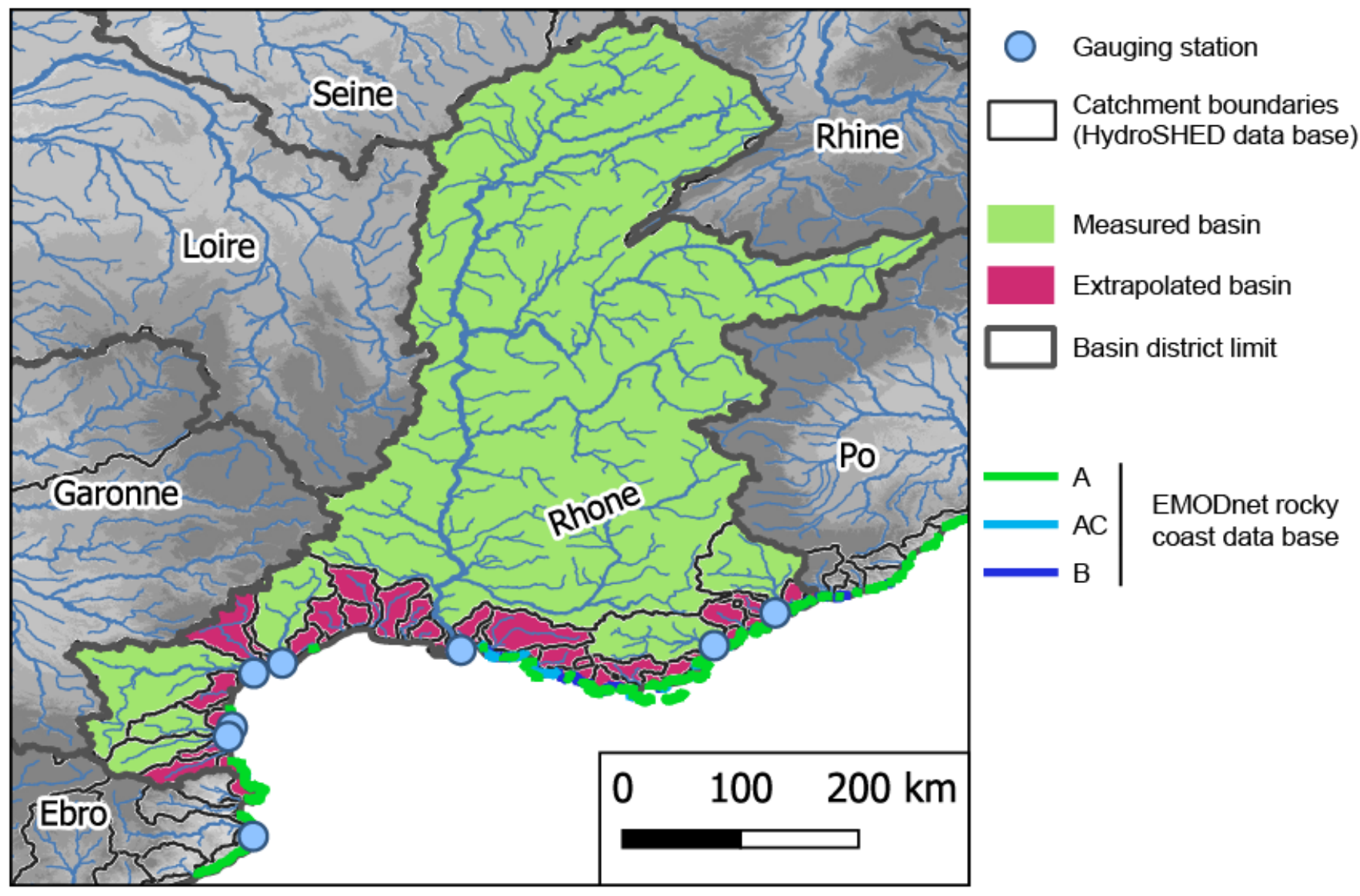

Fig. 5. Rhone basin district (as defined by the European Environment Agency). The basin district encompasses various sub-basins (HydroSHEDS data base; Lehner et al., 2008). The fluxes of some of them (green catchments) are measured at gauging stations (those drawn are from Milliman and Farnsworth, 2011). The others (in red, mainly close to the sea) were not measured but extrapolated with the average specific flux from the green areas. The EMODnet rock coast classification is shown for comparison. 
The first step was to partition the continent into meaningful entities in a consistent manner. The second step was to aggregate the sediment fluxes for specific gauging stations in order to document them. Such estimate was required to allow the comparison with our calculated flux from rock coasts. The average fluxes were calculated for each of the previously mentioned basin districts. The basin districts correspond to areas drained by numerous rivers. Some of them (usually the biggest ones) were monitored, resulting in sediment and dissolved material yields, which were compiled at a global scale in 2011 (Milliman and Farnsworth, 2011). For each basin district, we calculated the surface weighted average of the suspended solid specific fluxes for the monitored areas (shown in green in Figure 5). Catchments that are not monitored (as illustrated in red in Figure 5) also provide sediment fluxes but are not included in the database. Rather than ignoring these data, which would have underestimated the sediment flux, we calculated the surfaceweighted specific sediment flux and forced this value onto not monitored catchments (Figure 5, see Table Data S1 and the sensitivity analysis in the Supplementary Materials). For the study area, the area monitored for the suspended material is $\sim 43 \%$ of the total area (Table Data S1). We evaluated the dissolved solid fluxes in a similar way (Figure S2 and Table Data S1).

\section{Results}

The studied rock coasts supply a total mass of $111 \pm 65 \mathrm{Mt} / \mathrm{a}$ (Tables 1 and 3). At the same time, the solid discharge from rivers contributes $290 \mathrm{Mt} / \mathrm{a}$ (Table 3). The proportion of rock coast vs. river sediment supply for Europe is therefore $38 \%(r=0.38)$.

Table 3. Estimates of the European sedimentary flux into the ocean. For global fluxes, see Table S1.

\begin{tabular}{|c|c|c|c|}
\hline & Flux (Gt/a) & Area or length & Remarks and References \\
\hline \multirow{3}{*}{ Rivers } & $0.3-0.85$ & $5 \times 10^{6} \mathrm{~km}^{2}$ & $\begin{array}{l}\text { 0.6 Gt/a of dissolved solids from these rivers (Dedkov and } \\
\text { Gusarov, 2006; Milliman and Farnsworth, } 2011 \text { and } \\
\text { www.eurosion.org, 2004) }\end{array}$ \\
\hline & 0.34 & $4.85 \times 10^{6} \mathrm{~km}^{2}$ & This work (equivalent dissolved solids $0.42 \mathrm{Gt} / \mathrm{a}$ ) \\
\hline & 0.29 & $3.56 \times 10^{6} \mathrm{~km}^{2}$ & $\begin{array}{l}\text { This work, only the selected area (equivalent dissolved solids } \\
0.33 \mathrm{Gt} / \mathrm{a} \text { ) }\end{array}$ \\
\hline \multirow[t]{2}{*}{ Rock coasts } & $\begin{array}{l}0.046-0.176 \\
\text { (central value } \\
0.111)\end{array}$ & $127 \times 10^{3} \mathrm{~km}$ & This work, only the selected area $\left(65 \times 10^{3} \mathrm{~km}\right.$ of rock coast $)$ \\
\hline & 0.02 & $0.682 \times 10^{3} \mathrm{~km}$ & $\begin{array}{l}\text { Grand minimum (sum of the observations), this work and } \\
\text { (Prémaillon et al., 2018) }\end{array}$ \\
\hline
\end{tabular}

The uncertainty of our estimate for the European rock coast sediment supply is $\pm 65 \mathrm{Mt} / \mathrm{a}$, a value arising from the following uncertainties: $\pm 200 \mathrm{~kg} / \mathrm{m}^{3}$ for the densities, $10 \%$ for the cliff height and a $66 \%$ confidence uncertainty for the cliff retreat rates (Table 1 and paragraph 2.2). Consequently, 12 
the sediment flux due to the erosion of the selected rock coasts likely ranges between $\sim 46$ and 176 Mt/a. The lowest bound (46 Mt/a) is very conservative. Indeed, the first metric evaluated using monitored sites indicates $20 \mathrm{Mt} / \mathrm{a}$ (paragraph 2.2 and Table 3), almost half of the lowest bound, considering only $1 \%$ of the rock coastline.

An average $r$ ratio of 0.38 indicates that rivers still dominate the sediment supply at the continental level. However, basin districts where rivers dominate (Figure 3) are either draining mountainous areas (Po) or areas under the Mediterranean climate forcing (sensu Köppen-Geiger, Peel et al., 2007; cf Mesima Basin, Figure 3). Conversely, significant sinuosity of the coastline, as seen in deglaciated ria and fjord landscapes, favors sediment supply via coastal erosion versus rivers (e.g. Tana, Figure 3). Basin districts characterized by gentle topography display similar river and rock coasts contributions (Duero, Figure 3). As a whole, European watersheds that discharge into the Atlantic Ocean are dominated by sediment inputs from rock coasts $(r=1.2)$, those that discharge into the Baltic Sea are dominated by fluvial inputs $(r=0.4)$, and those that discharge into the Mediterranean Sea are strongly dominated by rivers $(r=0.2)$.

\section{Discussion}

Regarding the river fluxes, part of the measured solid flux may be trapped between the gauging station and the sea, in coastal plains and deltas. This is the case in the Ganges-Brahmaputra Basin where approximately $30 \%$ of the present day river load is naturally trapped in the delta floodplain (Goodbred and Kuehl, 1999). This decreases the contribution of rivers to ocean sediments (Milliman and Ren, 1995; Nyberg et al., 2018). Reducing the effective river solid discharge contribution would further increase the relative contribution of rock coast erosion to the ocean sediment budget.

Several anthropogenic modulations could also affect the coast-to-river ratio $(r)$. While extensive damming led to a considerable decrease in the solid river discharge (estimated to be $\sim 30 \%$ here, see Supplementary Materials), increasing the relative contribution of the coastal supply, agricultural practices and urbanization may have counteracting effect (Milliman and Ren, 1995; Li et al., 2020; Syvitski and Kettner, 2011; Ludwig et al., 2009). In addition, large coastal defenses have locally inhibited sediment supply (e.g. northeastern England; Pye and Blott, 2015). However, the use of pre-dam estimates only moderately affects the spatial distribution of $r$ (see Figure S1). Although it is a first estimate, we consider that the flux proposed in this study is illustrative of the current coastal input. Debates on anthropogenic impacts on sediment fluxes do not fundamentally alter the fact that rock coasts are of primary importance for the ocean sediment budget.

In this work, we consider that sediment traps such as beaches only delay the transit of sediments to the ocean for a period of time shorter than several millennia. Within this interval, the flux to the ocean will fluctuate, following the storage or removal of beach sand. Because they are open systems, beaches always loose sediments, which is balanced by a continuous supply of sediments from rivers and rock coasts. In the event of sediment deficit in rivers (e.g. due to damming), the beaches thin, exposing longer rock coastlines to erosion, which in turn supplies larger quantities of sediments, both net and relative, to the system (Willis and Griggs, 2003; Rao et al., 2010; Costa et al., 2015). This contribution is important for maintaining beach volumes and should be considered in coastal management (Costa et al., 2015; Mushkin et al., 2016). Nevertheless, this 
study points to a new source of sediments which will end up in ocean basins, irrespective of delayed delivery to the sink.

Our newly calculated value of rock coast sediment flux is only three times lower than the river sediment flux thus indicating that these two fluxes are of comparable amplitude. However, the nature of the transported sediment material is likely to be different both in terms of granulometry and degree of alteration. Sediments transported by large rivers are usually physically and chemically weathered by lengthy erosion processes and transport (Bouchez et al., 2012). Conversely, rock coast erosion delivers newly exposed rocks and some regolith material from the cliff top (Costa et al., 2015; Prémaillon et al., 2018). With regards to the granulometry, rivers deliver mostly fine material (suspended load usually accounts for more than $80 \%$ of the sediment flux, Turowski et al., 2010); however, even if this has not been studied in detail, our field experience suggests that cliff collapses must deliver relatively coarse material to the ocean.

Considering this new source of sediments to the ocean has broad consequences for global geochemical cycles. Since the mid-2000, researchers concur that the dissolved material input to the ocean is not sufficient to balance the marine geochemical budget (Jeandel and Oelkers, 2015). Imbalances have been identified by: (i) the development of isotopic measurements in sea water, notably Nd and Si (Lacan and Jeandel, 2005; Little et al., 2014; Kendall et al., 2017; Jeandel and Vance, 2018), and (ii) the reanalysis of the published geochemical signature of continental fluxes (Gislason et al., 2006; Oelkers et al., 2012; Jeandel and Oelkers, 2015). The budget imbalance arose because important processes and their possible contributions, revealed by the analyses of element's isotopes, were omitted. Among these missing processes, the dissolution of terrigenous sediments in sea water releases chemical species (Ehlert et al., 2016; Jeandel, 2016). This process is most active under shallow waters, where waves and currents stir the sediments, but the exact release mechanism is still debated (Ehlert et al., 2016; Jeandel, 2016). When dissolved in seawater, rock coast erosion products are likely to significantly contribute to the ocean chemistry. The release of fresh and reactive terrigenous material (e.g. Figure 1A) may be of particular importance for the $\mathrm{Si}$ and Fe cycles. For the Si cycle, whose dissolved river flux is currently estimated at 0.068 $\mathrm{Gt} / \mathrm{a}(2.4 \mathrm{Tmol} / \mathrm{a})$, the marine dissolution of terrigenous sediments could add between 30 and $120 \%$ of dissolved Si to the ocean (Jeandel and Oelkers, 2015; Fabre et al., 2019). This dissolution not only includes the 11-21 Gt/a of the riverine solid sediment flux (adding $3.8 \mathrm{Gt} / \mathrm{a}$ of Si; Viers et al., 2009) but also the 0.6-2.4 Gt/a of the rock coast input solid sediment flux (results from this work, upscaled at the global scale, see Supplementary Material). Since Si is a limiting element in much of the ocean, a larger Si flux would rapidly be assimilated by the local biology (Fripiat et al., 2011), accelerating its uptake from ocean water and sedimentation $(0.15 \mathrm{Gt} / \mathrm{a}$ or $5.3 \mathrm{Tmol} / \mathrm{a}$; Hayes et al., 2021). In the case of the Fe cycle, the mass budget imbalance is not as clear, but increasing the rock coast sediment flux by a factor 3 to 12 would make it a major Fe source (extrapolating from Raiswell et al., 2006, 12-30\% of the Fe reaching the continental shelf would come from coastal erosion). We conclude that the additional source of sediments from the erosion of the rock coasts is a key process of the geochemical cycles.

The contribution of rock coast erosion may have fluctuated over the Holocene and the glacial cycles. During the Holocene, the deceleration of the sea-level rise at $\sim 6 \mathrm{ka} \mathrm{BP}$ (except at high latitude (Clark et al., 1978) was probably rapidly followed by a worldwide sediment accretion represented by ancient beaches and mangroves that are often dated back to $\sim 5 \mathrm{ka} \mathrm{BP}$ (Woodroffe 
et al., 1985; Stapor et al., 1991; Harvey, 2006). During that short period of time ( 6 to 5 ka BP), beaches were not yet established, meaning that cliffs were found on most of the world's coast, likely shedding large amounts of sediments into the sea before the progradation of the beaches shielded some of the coastlines (e.g. the eastern USA; Belknap and Kraft, 1985). With the exception of the 20th century sea level rise caused by human-driven global warming, the current sea level, since $6 \mathrm{ka} \mathrm{BP}$, is marked by slow relative changes. Unshielded rock coasts have first retreated by purging (peri-)glacially autochtonous weathered material, initially lying at the coast (Griggs and Trenhaile, 1994). Today, cliff-retreat rates mostly come from non-weathered cliff erosion (Prémaillon et al., 2018). We can vouch for this assertion based on the millennial retreat rates calculated from ${ }^{10} \mathrm{Be}$ cosmogenic nuclide (Regard et al., 2012; Hurst et al., 2016; Swirad et al., 2020; Duguet et al., 2021). These millennial rates are either similar to estimates of the current retreat rate (Regard et al., 2012; Swirad et al., 2020) or lower, indicating a recent and gentle acceleration, probably caused by human activity (Hurst et al., 2016; Duguet et al., 2021).

Can we speculate on the past evolution of the rock coast's contribution to global sediment flux? During the LGM ( 20 ka BP), the sea level was $\sim 120 \mathrm{~m}$ below present. Using the most recent glacio-isostatic database (Peltier et al., 2015), we show that the total coast length was over $20 \%$ shorter than at present (paragraph 2.3 and Figure 3). As a consequence, it is possible that the sedimentary yield from the rock coast erosion during the LGM was reduced in a similar proportion. In turn, the coeval evolution of the continental fluxes during glacial cycles is still poorly constrained. It is currently impossible to accurately evaluate sediment yield fluctuations because past river catchment denudation rate measurements are too sparse. It is suspected, however, that, with the notable exception of the monsoonal Asia (Clift and Jonell, 2021), glacial periods produced more sediments. Indeed, during the last two glacial-interglacial cycles (the last $150 \mathrm{ka}$ ), a deglacial sediment pulse has been released in the Alps and Himalayas (Vance et al., 2009; Mariotti et al., 2021). This reflects the increase in glacial denudation, as reported by Raiswell et al. (2006). Sediment export is controlled by rivers and icebergs. During glacial periods, icebergs supplied 35 times more sediments than today (Raiswell et al., 2006). But even though glacial sediment production was higher, the river outflux to the ocean was dampened by temporary storage on the continent, in terraces and at river mouths during the Holocene sea level rise. Consequently, there is no clear argument to support a strong imbalance between rock coast and river sediment supply to the ocean during glacial-interglacial cycles. Therefore, we propose that the order of magnitude of the relative coastal/river fluxes estimated in this contribution may hold for the Quaternary.

The quantification presented here is based on an empirical coastal erosion model. At the European scale, this model could be improved by further studies in unexplored areas such as Scandinavia. Wave energy is not considered as an important erosion driver in this model (Prémaillon et al., 2018), which deserves further investigation (Zhao et al., 2020). Beyond the European scale, the next step forward is to extend the model on a global scale. This upscaling requires data from poorly monitored coastlines in different climatic contexts, such as South America, Africa, southern Asia or more specifically volcanic islands. 


\section{Conclusion}

Taking Europe as an example, and using the most-complete cliff retreat rates database available to date, we demonstrate that the rock coast sediment supply to the global ocean is not as marginal as previously thought. At the scale of Europe, the magnitude of this flux is only three times lower than the river solid discharge. To extrapolate our findings at the global scale, a quantification of the rock coast erosion should be performed for the other continents, not yet possible because of the lack of relevant data. Nevertheless, this additional sedimentary source must be further investigated for: (i) its signature in the sedimentary records of ocean basins; (ii) its effects on the geochemical ocean budget; and (iii) the consequences of rising sea level on rock coast erosion rates.

Acknowledgments: we would like to thank the BRGM and Region Midi-Pyrénées for providing the funding for MP's $\mathrm{PhD}$ thesis.

Author's contributions: VR took part in every task; MP conducted the preliminary work defining the retreat rates in function of the coastal type; TD supervised MP's PhD work together with VR; each author took part in the validation and writing of the original draft.

Competing interests: The authors declare that they have no competing interests.

\section{References}

Belknap, D., and Kraft, J., 1985, Influence of antecedent geology on stratigraphic preservation potential and evolution of Delaware's barrier systems: Marine Geology, v. 63, p. 235-262, doi:10.1016/0025-3227(85)90085-4.

Bouchez, J., Gaillardet, J., Lupker, M., Louvat, P., France-Lanord, C., Maurice, L., Armijos, E., and Moquet, J.-S., 2012, Floodplains of large rivers: Weathering reactors or simple silos? Chemical Geology, v. 332, p. 166-184, doi:10.1016/j.chemgeo.2012.09.032.

Clark, J.A., Farrell, W.E., and Peltier, W.R., 1978, Global changes in postglacial sea level: A numerical calculation: Quaternary Research, v. 9, p. 265-287, doi:10.1016/00335894(78)90033-9.

Clift, P.D., and Jonell, T.N., 2021, Monsoon controls on sediment generation and transport: Mass budget and provenance constraints from the Indus River catchment, delta and submarine fan over tectonic and multimillennial timescales: Earth-Science Reviews, v. 220, p. 103682, doi:10.1016/j.earscirev.2021.103682. 
Costa, S., Letortu, P., and Laignel, B., 2015, The Hydro-sedimentary System of the UpperNormandy Coast: Synthesis, in Maanan, M. and Robin, M. eds., Sediment Fluxes in Coastal Areas, Dordrecht, Springer Netherlands, Coastal Research Library, p. 121-147, doi:10.1007/978-94-017-9260-8_6.

Dedkov, A., and Gusarov, A., 2006, Suspended sediment yield from continents into the World Ocean: spatial and temporal changeability: Sediment Dynamics and the Morphology of Fluvial Systems. IAHS Publication, v. 396, p. 3-11.

Duguet, T., Duperret, A., Costa, S., Regard, V., and Maillet, G., 2021, Coastal chalk cliff retreat rates during the Holocene, inferred from submarine platform morphology and cosmogenic exposure along the Normandy coast (NW France): Marine Geology, v. 433, p. 106405, doi:10.1016/j.margeo.2020.106405.

Ehlers, T.A., Gibbard, P.L., and Hughes, P.D. (Eds.), 2011, Quaternary Glaciations - Extent and Chronology, Volume $15 \quad-\quad 1$ st $\quad$ Edition: $1126 \quad$ p., https://www.elsevier.com/books/quaternary-glaciations-extent-andchronology/ehlers/978-0-444-53447-7 (accessed September 2019).

Ehlert, C., Reckhardt, A., Greskowiak, J., Liguori, B.T.P., Böning, P., Paffrath, R., Brumsack, H.J., and Pahnke, K., 2016, Transformation of silicon in a sandy beach ecosystem: Insights from stable silicon isotopes from fresh and saline groundwaters: Chemical Geology, v. 440, p. 207-218, doi:10.1016/j.chemgeo.2016.07.015.

European Environment Agency European Environment Agency basin divisions (https://www.eea.europa.eu/ds_resolveuid/XJN28HRUCO):

Fabre, S., Jeandel, C., Zambardi, T., Roustan, M., and Almar, R., 2019, An Overlooked Silica Source of the Modern Oceans: Are Sandy Beaches the Key? Frontiers in Earth Science, v. 7, doi:10.3389/feart.2019.00231.

Fripiat, F., Cavagna, A.-J., Savoye, N., Dehairs, F., André, L., and Cardinal, D., 2011, Isotopic constraints on the Si-biogeochemical cycle of the Antarctic Zone in the Kerguelen area (KEOPS): Marine Chemistry, v. 123, p. 11-22, doi:10.1016/j.marchem.2010.08.005.

Galy, V., France-Lanord, C., Beyssac, O., Faure, P., Kudrass, H., and Palhol, F., 2007, Efficient organic carbon burial in the Bengal fan sustained by the Himalayan erosional system: Nature, v. 450, p. 407-410, doi:10.1038/nature06273.

Gislason, S.R., Oelkers, E.H., and Snorrason, A., 2006, Role of river-suspended material in the global carbon cycle: Geology, v. 34, p. 49-52, doi:10.1130/G22045.1.

Goodbred, S., and Kuehl, S., 1999, Holocene and modern sediment budgets for the GangesBrahmaputra river system: Evidence for highstand dispersal to flood-plain, shelf, and deepsea depocenters: Geology, v. 27, p. 559-562, doi:10.1130/00917613(1999)027<0559:HAMSBF>2.3.CO;2. 
Griggs, G.B., and Trenhaile, A., 1994, Coastal Cliffs and Platforms, in Carter, R.W.G. and Woodroffe, C.D., Eds., Coastal Evolution: Late Quaternary Shoreline Morphodynamics, Cambridge, Cambridge University Press, p. 425-450.

Harvey, N., 2006, Holocene Coastal Evolution: Barriers, Beach Ridges, and Tidal Flats of South Australia: Journal of Coastal Research, v. 22, p. 90-99.

Hay, W.W., 1998, Detrital sediment fluxes from continents to oceans: Chemical Geology, v. 145, p. 287-323, doi:10.1016/S0009-2541(97)00149-6.

Hayes, C.T. et al., 2021, Global Ocean Sediment Composition and Burial Flux in the Deep Sea: Global Biogeochemical Cycles, v. 35, p. e2020GB006769, doi:https://doi.org/10.1029/2020GB006769.

Higgins, C., 1980, Nips, notches, and the solution of coastal limestone: an overview of the problem with examples from Greece: Estuarine and Coastal Marine Science, v. 10, p. 15-30, doi:10.1016/S0302-3524(80)80046-6.

Hoek, E., and Brown, E., 1997, Practical estimates of rock mass strength: International journal of rock mechanics and mining sciences, v. 34, p. 1165-1186.

Hurst, M.D., Rood, D.H., Ellis, M.A., Anderson, R.S., and Dornbusch, U., 2016, Recent acceleration in coastal cliff retreat rates on the south coast of Great Britain: Proceedings of the National Academy of Sciences, v. 113, p. 13336-13341, doi:10.1073/pnas.1613044113.

Jeandel, C., 2016, Overview of the mechanisms that could explain the 'Boundary Exchange' at the land-ocean contact: Philosophical Transactions of the Royal Society A: Mathematical, Physical and Engineering Sciences, v. 374, p. 20150287, doi:10.1098/rsta.2015.0287.

Jeandel, C., and Oelkers, E., 2015, The influence of terrigenous particulate material dissolution on ocean chemistry and global element cycles: Chemical Geology, v. 395, p. 50-66, doi:10.1016/j.chemgeo.2014.12.001.

Jeandel, C., and Vance, D., 2018, New Tools, New Discoveries in Marine Geochemistry: Elements, v. 14, p. 379-384, doi:10.2138/gselements.14.6.379.

Jickells, T.D. et al., 2005, Global Iron Connections Between Desert Dust, Ocean Biogeochemistry, and Climate: Science, v. 308, p. 67-71, doi:10.1126/science.1105959.

Kendall, B., Dahl, T.W., and Anbar, A.D., 2017, Good Golly, Why Moly? THE STABLE ISOTOPE GEOCHEMISTRY OF MOLYBDENUM, in Teng, F.Z., Watkins, J., and Dauphas, N. eds., Non-Traditional Stable Isotopes, Chantilly, Mineralogical Soc Amer \& Geochemical Soc, v. 82, p. 683-732. 
Lacan, F., and Jeandel, C., 2005, Neodymium isotopes as a new tool for quantifying exchange fluxes at the continent-ocean interface: Earth and Planetary Science Letters, v. 232, p. 245257, doi:10.1016/j.epsl.2005.01.004.

Lamb, S., and Davis, P., 2003, Cenozoic climate change as a possible cause for the rise of the Andes: Nature, v. 425, p. 792-797.

Lehner, B., Verdin, K., and Jarvis, A., 2008, New Global Hydrography Derived From Spaceborne Elevation Data: Eos, Transactions American Geophysical Union, v. 89, p. 93, doi:10.1029/2008EO100001.

Li, L. et al., 2020, Global trends in water and sediment fluxes of the world's large rivers: Science Bulletin, v. 65, p. 62-69, doi:10.1016/j.scib.2019.09.012.

Little, S., Vance, D., Walker-Brown, C., and Landing, W., 2014, The oceanic mass balance of copper and zinc isotopes, investigated by analysis of their inputs, and outputs to ferromanganese oxide sediments: Geochimica et Cosmochimica Acta, v. 125, p. 673-693, doi:10.1016/j.gca.2013.07.046.

Ludwig, W., Dumont, E., Meybeck, M., and Heussner, S., 2009, River discharges of water and nutrients to the Mediterranean and Black Sea: Major drivers for ecosystem changes during past and future decades? Progress in Oceanography, v. 80, p. 199-217, doi:10.1016/j.pocean.2009.02.001.

Ludwig, W., and Probst, J.-L., 1998, River sediment discharge to the oceans; present-day controls and global budgets: American Journal of Science, v. 298, p. 265-295, doi:10.2475/ajs.298.4.265.

Luijendijk, A., Hagenaars, G., Ranasinghe, R., Baart, F., Donchyts, G., and Aarninkhof, S., 2018, The State of the World's Beaches: Scientific Reports, v. 8, p. 6641, doi:10.1038/s41598018-24630-6.

Mackenzie, F.T., and Garrels, R., 1971, Evolution of sedimentary rocks: Norton New York.

Mahowald, N.M., Baker, A.R., Bergametti, G., Brooks, N., Duce, R.A., Jickells, T.D., Kubilay, N., Prospero, J.M., and Tegen, I., 2005, Atmospheric global dust cycle and iron inputs to the ocean: ATMOSPHERIC IRON DEPOSITION: Global Biogeochemical Cycles, v. 19, p. n/a-n/a, doi:10.1029/2004GB002402.

Mandelbrot, B., 1967, How Long Is the Coast of Britain? Statistical Self-Similarity and Fractional Dimension: Science, v. 156, p. 636-638, doi:10.1126/science.156.3775.636.

Mariotti, A., Blard, P.-H., Charreau, J., Toucanne, S., Jorry, S.J., Molliex, S., Bourlès, D.L., Aumaître, G., and Keddadouche, K., 2021, Nonlinear forcing of climate on mountain denudation during glaciations: Nature Geoscience, v. 14, p. 16-22, doi:10.1038/s41561020-00672-2. 
Milliman, J.D., 2001, River Inputs, in Encyclopedia of Ocean Sciences, Elsevier, p. 2419-2427, doi:10.1006/rwos.2001.0074.

Milliman, J., and Farnsworth, K., 2011, River Discharge to the Coastal Ocean: A Global Synthesis: Cambridge, Cambridge University Press, doi:10.1017/CBO9780511781247.

Milliman, J., and Ren, M., 1995, River flux to the sea: impact of human intervention on river systems and adjacent coastal areas: Impact on coastal habitation, p. 57-83.

Mushkin, A., Katz, O., Crouvi, O., Alter, S.R., and Shemesh, R., 2016, Sediment contribution from Israel's coastal cliffs into the Nile's littoral cell and its significance to cliff-retreat mitigation efforts: Engineering Geology, v. 215, p. 91-94, doi:10.1016/j.enggeo.2016.11.005.

Naylor, L., Coombes, M., and Viles, H., 2012, Reconceptualising the role of organisms in the erosion of rock coasts: a new model: Geomorphology, v. 157, p. 17-30.

Nyberg, B., Gawthorpe, R.L., and Helland-Hansen, W., 2018, The distribution of rivers to terrestrial sinks: Implications for sediment routing systems: Geomorphology, v. 316, p. 123, doi:10.1016/j.geomorph.2018.05.007.

Oelkers, E., Jones, M., Pearce, C., Jeandel, C., Eiriksdottir, E., and Gislason, S., 2012, Riverine particulate material dissolution in seawater and its implications for the global cycles of the elements: Comptes Rendus Geoscience, v. 344, p. 646-651, doi:10.1016/j.crte.2012.08.005.

Peel, M.C., Finlayson, B.L., and McMahon, T.A., 2007, Updated world map of the Köppen-Geiger climate classification: Hydrology and Earth System Sciences, v. 11, p. 1633-1644, doi:10.5194/hess-11-1633-2007.

Peltier, W.R., Argus, D.F., and Drummond, R., 2015, Space geodesy constrains ice age terminal deglaciation: The global ICE-6G_C (VM5a) model: Journal of Geophysical Research: Solid Earth, v. 120, p. 450-487, doi:10.1002/2014JB011176.

Peucker-Ehrenbrink, B., 2009, Land2Sea database of river drainage basin sizes, annual water discharges, and suspended sediment fluxes: LAND2SEA RIVER BASIN DATABASE: Geochemistry, Geophysics, Geosystems, v. 10, p. n/a-n/a, doi:10.1029/2008GC002356.

Prémaillon, M., Regard, V., Dewez, T.J.B., and Auda, Y., 2018, GlobR2C2 (Global Recession Rates of Coastal Cliffs): a global relational database to investigate coastal rocky cliff erosion rate variations: Earth Surface Dynamics, v. 6, p. 651-668, doi:https://doi.org/10.5194/esurf-6-651-2018.

Pye, K., and Blott, S., 2015, Spatial and temporal variations in soft-cliff erosion along the Holderness coast, East Riding of Yorkshire, UK: Journal of Coastal Conservation, v. 19, p. 785-808, doi:10.1007/s11852-015-0378-8. 
Rachold, V., Grigoriev, M., Are, F., Solomon, S., Reimnitz, E., Kassens, H., and Antonow, M., 2000, Coastal erosion vs riverine sediment discharge in the Arctic Shelf seas: International Journal of Earth Sciences, v. 89, p. 450-460, doi:10.1007/s005310000113.

Raiswell, R., Tranter, M., Benning, L.G., Siegert, M., De'ath, R., Huybrechts, P., and Payne, T., 2006, Contributions from glacially derived sediment to the global iron (oxyhydr)oxide cycle: Implications for iron delivery to the oceans: Geochimica et Cosmochimica Acta, v. 70, p. 2765-2780, doi:10.1016/j.gca.2005.12.027.

Rao, K.N., Subraelu, P., Kumar, K.C.V.N., Demudu, G., Malini, B.H., Rajawat, A.S., and Ajai, 2010, Impacts of sediment retention by dams on delta shoreline recession: evidences from the Krishna and Godavari deltas, India: Earth Surface Processes and Landforms, v. 35, p. 817-827, doi:10.1002/esp.1977.

Regard, V., Dewez, T., Bourlès, D.L., Anderson, R.S., Duperret, A., Costa, S., Leanni, L., Lasseur, E., Pedoja, K., and Maillet, G.M., 2012, Late Holocene seacliff retreat recorded by 10Be profiles across a coastal platform: Theory and example from the English Channel: Quaternary Geochronology, v. 11, p. 87-97, doi:10.1016/j.quageo.2012.02.027.

Sabatier, F., Maillet, G., Provansal, M., Fleury, T.J., Suanez, S., and Vella, C., 2006, Sediment budget of the Rhone delta shoreface since the middle of the 19th century: Marine Geology, v. 234, p. 143-157.

Stapor, F.W., Mathews, T.D., and Lindfors-Kearns, F.E., 1991, Barrier-Island Progradation and Holocene Sea-Level History in Southwest Florida: Journal of Coastal Research, v. 7, p. 815-838.

Swirad, Z.M., Rosser, N.J., Brain, M.J., Rood, D.H., Hurst, M.D., Wilcken, K.M., and Barlow, J., 2020, Cosmogenic exposure dating reveals limited long-term variability in erosion of a rocky coastline: Nature Communications, v. 11, p. 3804, doi:10.1038/s41467-020-176119.

Syvitski, J., and Kettner, A., 2011, Sediment flux and the Anthropocene: Philosophical Transactions of the Royal Society A: Mathematical, Physical and Engineering Sciences, v. 369, p. 957-975.

Syvitski, J., Peckham, S., Hilberman, R., and Mulder, T., 2003, Predicting the terrestrial flux of sediment to the global ocean: a planetary perspective: Sedimentary Geology, v. 162, p. 524, doi:10.1016/S0037-0738(03)00232-X.

Syvitski, J.P.M., Vörösmarty, C.J., Kettner, A.J., and Green, P., 2005, Impact of Humans on the Flux of Terrestrial Sediment to the Global Coastal Ocean: Science, v. 308, p. 376-380, doi:10.1126/science.1109454.

Turowski, J.M., Rickenmann, D., and Dadson, S.J., 2010, The partitioning of the total sediment load of a river into suspended load and bedload: a review of empirical data: The partitioning 
of sediment load: Sedimentology, v. 57, p. 1126-1146, doi:10.1111/j.13653091.2009.01140.x.

Vance, D., Teagle, D.A.H., and Foster, G.L., 2009, Variable Quaternary chemical weathering fluxes and imbalances in marine geochemical budgets: Nature, v. 458, p. 493-496, doi:10.1038/nature07828.

Viers, J., Dupré, B., and Gaillardet, J., 2009, Chemical composition of suspended sediments in World Rivers: New insights from a new database: Science of The Total Environment, v. 407, p. 853-868, doi:10.1016/j.scitotenv.2008.09.053.

Wessel, P., and Smith, W., 1996, A global, self-consistent, hierarchical, high-resolution shoreline database: Journal of Geophysical Research-Solid Earth, v. 101, p. 8741-8743, doi:10.1029/96JB00104.

Wilkinson, B.H., and McElroy, B.J., 2007, The impact of humans on continental erosion and sedimentation: Geological Society of America Bulletin, v. 119, p. 140-156, doi:10.1130/B25899.1.

Willis, C.M., and Griggs, G.B., 2003, Reductions in Fluvial Sediment Discharge by Coastal Dams in California and Implications for Beach Sustainability: The Journal of Geology, v. 111, p. 167-182, doi:10.1086/345922.

Woodroffe, C., Thom, B., and Chappell, J., 1985, Development of widespread mangrove swamps in mid-Holocene times in northern Australia: Nature, v. 317, p. 711, doi:10.1038/317711a0.

Young, A., and Carilli, J., 2019, Global distribution of coastal cliffs: Earth Surface Processes and Landforms, doi:10.1002/esp.4574.

Zhao, Z., Mitchell, N.C., Quartau, R., Ramalho, R.S., and Rusu, L., 2020, Coastal erosion rates of lava deltas around oceanic islands: Geomorphology, p. 107410, doi:10.1016/j.geomorph.2020.107410. 